\title{
МОДЕЛЮВАННЯ ЗАВИТКИ ВНУТРІШНЬОГО ВУХА ЛЮДИНИ
}

\author{
С. А. Найда, О. О. Зубченко \\ Національний технічний університет України "Київський політехнічний інститут"
}

\begin{abstract}
Проведено моделювання завитки внутрішнього вуха людини за допомогою довгої лінії. Встановлені наступні закономірності функціонування завитки: без врахування гнучкостей рейснерової і базилярної мембран різниця тиску на стінках завиткового ходу не перевищує 3,6 \% від тиску в ділянці овального вікна; розподіл різниці звукового тиску коливається в часі з частотою $w$; врахування гнучкості мембрани і залежності положення резонансів від $f$ визначаються неоднорідністю базилярної мембрани; біжуча хвиля різниці $p_{v t}(x, t)$ існує тільки поблизу резонансу на кожній частоті, де наростання амплітуди коливань до максимуму відбувається за багато періодів резонансної частоти.

Мале відносне значення амплітуди тиску біжучої хвилі могло стати причиною того, що робота Петерсона і Богерта не отримала подальшого розвитку.
\end{abstract}

Ключові слова: завитка, довга лінія, базилярна мембрана, рейснерова мембрана.

\section{МОДЕЛИРОВАНИЕ УЛИТКИ ВНУТРЕННЕГО УХА ЧЕЛОВЕКА}

Национальный технический университет Украины "Киевский политехнический институт"

\footnotetext{
Проведено моделирования улитки внутреннего уха человека с помощью длинной линии. Установлены следующие закономерности функционирования улитки: без учёта гибкостей рейснеровой и базилярной мембран разность давлений на стенках улиткового хода не превышает 3,6 \% от давления в области овального окна; распределение разности звукового давления колеблется во времени с частотой $w$; учёт гибкости мембраны и зависимость положения резонансов от $f$ определяются неоднородностью базилярной мембраны; бегущая волна разности $p_{v t}(x, t)$ существует только вблизи резонанса на каждой частоте, где нарастание амплитуды колебаний до максимума происходит за много периодов резонансной частоты.

Малое относительное значение амплитуды давления бегущей волны могло стать причиной того, что работа Петерсона и Богерта не получила дальнейшего развития.
}

Ключевые слова: улитка, длинная линия, базилярная мембрана, рейснерова мембрана.

\section{SIMULATION OF A COCHLEA OF AN INTERIOR EAR OF THE HUMAN}

\section{S. A. Naida, O. A. Zubchenko \\ National Technical University of Ukraine "Kyiv Polytechnic Institute"}

There was conducted the simulations of a cochlea of an interior ear of the human by means of a long line. The following regularities of operation of a cochlea were determined: without the count of flexibilities Reissner's and basilar membranes swing pressure on walls of a cochlear course does not exceed 3,6 \% from pressure in the field of an oval window; allocation of a differential of sound pressure fluctuates in a time with frequency $w$; taking into account the slenderness of a membrane and dependence of a standing of resonances from $f$ are spotted by non-uniformity of a basilar membrane; the differential travelling wave exists $p_{v t}(x, t)$ only near to a resonance on each frequency where the amplitude buildup of oscillations to a maximum happens for many continuances of resonance frequency.

Small relative meaning of range of pressure of travelling wave could become the parent of that Peterson's and Bogert's work has not had the further evolution.

Key words: a cochlea, a long line, a basilar membrane, Reissner's membrane.

Вступ. Ключовим у з'ясуванні механізму перетворення акустичних сигналів в електричні в завитці внутрішнього вуха людини до останнього часу залишається (C) С. А. Найда, О. О. Зубченко питання, яка 3 теорій його пояснює: резонансна теорія Гельмгольца або теорія рухомої хвилі Бекеші. При цьому об' єктом дослідження стали гідромеханічні та екві- 
валентні їм електричні моделі завитки, аналогічні тим, які розробляв Бекеші для демонстрації рухомих хвиль. Припускалося, що завитка є трубкою, заповненою рідиною (перилімфою), перегородженою по своїй довжині основною (базилярною) мембраною. Довжина завитки близько 35 мм, а базилярної мембрани близько 32 мм, іï ширина при основі 0,05 мм, а біля вершини 0,5 мм. При основі вона значно жорсткіша і тонша, ніж біля вершини, де вона піддатлива і масивна. Тому резонансні властивості базилярної мембрани неперервно змінюються уздовж їі довжини. На ній покоїться орган Корті. Разом 3 декількома типами підтримувальних клітин орган Корті містить близько 30000 чутливих клітин, до яких підходять закінчення слухового нерва. При коливаннях основної мембрани ці клітини збуджуються і передають сигнали волокнам слухових нервів. Бекеші розробив модель мембрани з гуми і показав, що, змінюючи іï товщину, можна домогтися будь-якого типу коливань з тих, які передбачала кожна з чотирьох існуючих на той момент теорій.

Вважаючи, що першим кроком в кількісному описі процесів в завитці можна обмежитися побудовою моделі, яка описує зміщення базилярної мембрани, були запропоновані апроксимації передатної функції мембрани, розрахованої за фізіологічними даними Бекеші, отриманими для завитки. I, як не дивно, майже усі дослідники цим і обмежилися. Досить сказати, що з 232 посилань в дисертації [1] тільки у одній роботі [2], на результатах якої зупинився Фланаган [3], не помічаючи різниці між моделлю мембрани i моделлю завитки, відзначається: "В попередніх розділах властивості середнього вуха і базилярної мембрани описувалися рівняннями передачі з входу на вихід. Проте, у ряді робіт внутрішнє вухо розглядається як система $з$ розподіленими параметрами і детально вивчається дія цієї системи...".

Метою даної роботи є побудова моделі завитки, яка дозволяє проаналізувати процеси, що відбуваються у внутрішньому вусі людини. Для цього використано модель довгої лінії.

\section{Модель довгої лінії}

Завитка є конусом, що складається 3 двох паралельних половин: зворотного і прямого конусних рупорів, розділених між собою завитковим ходом з в'язкою ендолімфою, відокремленим від вестибулярного каналу рейснеровою мембраною, а від тимпанального каналу - базилярною мембраною. Звернемо увагу на те, що система вже послідовного з'єднання зворотного і прямого рупорів $є$ в слуховій трубі середнього вуха.
Спочатку зупинимось на властивостях рупорів. Умовою відсутності поперечних хвиль у хвилеводі $є$ $f<f_{\text {кр }}=1,84 \cdot \frac{c}{2 \pi a} ;$ де $a-$ радіус більшого з перерізів рупора. У випадку завитки $S_{0}$ біля вершини дорівнює $1 \mathrm{Mм}^{2}$ ( $\left.a \sim 1 \mathrm{Mм}\right), S(I) \sim 4 \mathrm{Mм}^{2}(a \sim 2 \mathrm{Mм}) f<50$ кГц, ця умова виконується.

В акустиці, на відміну від механіки, замість двох величин, звукового тиску та коливальної швидкості, використовується одна величина - потенціал коливальної швидкості. Хвиля описується хвильовим рівнянням Вебстера. Для синусоїдальних коливань воно має вигляд [4]:

$\frac{d^{2} \Phi}{d x^{2}}+\frac{1}{S} \frac{d S}{d x} \frac{d \Phi}{d x}+k^{2} \Phi=0$

де $k=\omega / c_{0}\left(\mathrm{c}_{0}=1500 \mathrm{~m} /\right.$ с у воді $)$.

Для хвиль в безмежно довгому експоненційному рупорі:

$\Phi(x)=A e^{\gamma_{1} x}$,

де $\gamma_{1}=-\delta-\sqrt{\delta^{2}-k^{2}}=-\delta-j k \sqrt{1-\frac{\delta^{2}}{k^{2}}}$

$\Phi(x)=A e^{-\delta x} e^{-j k^{\prime} x}$

де

$\xi^{\prime}=k \sqrt{1-\frac{\delta^{2}}{k^{2}}}=\frac{\omega}{c_{0}} \sqrt{1-\left(\frac{\delta c_{0}}{\omega}\right)^{2}}$.

Співвідношення (3) має сенс лише до тих пір, поки $\mathrm{k}^{1}$ - дійсна величина, тобто другий член підкореневого виразу (4) менше одиниці. Тому частота, при якій ця умова порушується і хвильовий процес в рупорі перестає існувати, називається критичною:

$\omega_{\mathrm{kp}}=\delta c_{0}, \delta=\frac{1}{2 x} \ln \frac{S(x)}{S_{0}}$ або $\delta=\frac{1}{2 l} \ln \frac{S(I)}{S_{0}}$ для ру-

пора кінцевої довжини.

Для конічного рупора $S=S_{0}\left(1+\alpha_{n} x\right)^{n}(n=1,2$,

3....). При $n=2: S=S_{0}\left(1+\alpha_{2} x\right)^{2}=S_{0}\left(\frac{x}{x_{0}}\right)^{2}$, де $x_{0}=\frac{1}{\alpha_{2}}=\frac{1}{\sqrt{\frac{S_{1}}{S_{0}}-1}}$ 
У випадку завитки $\sqrt{\frac{S_{I}}{S_{0}}}=2$ i $x_{0}=I$, початок координат у вершині конуса, а є тепер вже відстанню від вершини конуса, тобто включає в себе $\mathrm{x}_{0}$.

Хвильове рівняння має вигляд:

$\frac{d^{2} \Phi}{d x^{2}}+\frac{2}{r} \frac{d \Phi}{d x}+k^{2} \Phi=0$ або

$\frac{\partial^{2}(r \Phi)}{\partial t^{2}}=c_{0}^{2} \frac{\partial^{2}(r \Phi)}{\partial r^{2}}$

тобто описує розбіжну хвилю, для якої

$$
\Phi=\frac{A}{r} e^{j\left(\omega t-k^{\prime} r\right)}
$$

$$
\text { де }|x|=r ; p=\rho_{0} \frac{\partial \Phi}{\partial t}=j \omega \rho_{0} \Phi ; \xi=-\frac{\partial \Phi}{\partial x} \text {. }
$$

Отже, Ф, а разом і р, по осі рупора спадають, а частотна характеристика (ЧХ) є ЧХ фільтра верхніх частот.

В зворотному рупорі г зменшується, а $\Phi$ і $p$ наростають.

Схематичне зображення завитки показано на рисунку 1.

\$0)

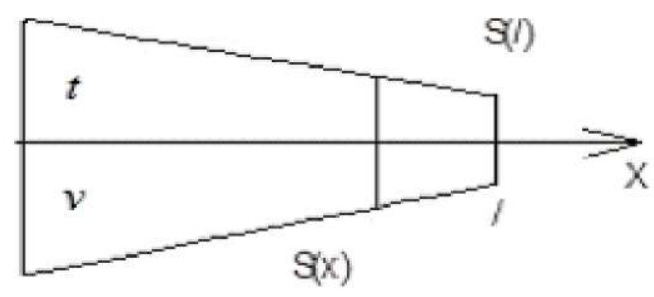

Puc. 1. Ідеалізоване схематичне зображення завитки.

Припускається, що залежність площ поперечного перерізу присінкових (вестибулярних) і тимпанальних (барабанних) сходів описується однією і тією ж функцією $\mathrm{S}_{0}(\times)$. Ширина базилярної мембрани позначається через $b(x)$, а маса, опір і жорсткість базилярної мембрани (точніше, ходу завитки, що розділяє канали), що припадають на одиницю поверхні, представлені відповідно функціями $m(x), r(x)$ і $k(x)$. Використані механічні сталі, розраховані за даними фізіологічних вимірів Бекеші.

Прийняті наступні припущення. Амплітуди усіх коливань досить малі, так що нелінійні ефекти виключаються. Рух стремінця викликає в каналах тільки плоскі хвилі стиснення. Відмітимо, що основою для цього є той факт, що Бекеші, виконуючи вимір пере- датної функції середнього вуха, безпосередньо спостерігав величину зміщення круглого вікна. Вертикальна складова швидкості руху перилімфи нехтовно мала. Елементи мембрани механічно не зв'язані.

Для опису системи необхідно скласти рівняння плоскої хвилі стиснення, що поширюється в каналах, і рівняння руху деякого даного елементу мембрани. Для плоскої хвилі в каналах звуковий тиск $р$ та швидкість руху частинки $и$ зв'язані рівнянням руху [2]:

$\rho \frac{\partial u}{\partial t}=-\frac{\partial p}{\partial x}$

де $\rho$ - середня щільність перилімфи.

Рівняння неперервності (збереження маси) в кожному каналі з урахуванням гнучкості однієї із стінок

$\frac{\partial\left(u_{v, t} s\right)}{\partial x}=-\frac{s}{\rho c^{2}} \frac{\partial p_{v, t}}{\partial t} \mp v \cdot b$,

де $v$ - швидкість руху мембрани; індекси $v$ та $t$ позначають відповідно присінкові і барабанні сходи. Беручи похідну по $t$ від обох частин (7) і враховуючи (6), отримуємо:

$\frac{\partial}{\partial t} \frac{\partial\left(u_{v, t} s\right)}{\partial x}=\frac{\partial}{\partial x}\left(s \frac{\partial u_{v, t}}{\partial t}\right)=-\frac{1}{\rho} \frac{\partial}{\partial x}\left(S \frac{\partial p_{v, t}}{\partial x}\right)=-\frac{S}{\rho c^{2}} \frac{\partial^{2} p_{v, t}}{\partial t^{2}} \mp \frac{\partial v}{\partial t} \cdot b$

Звідси:

$\frac{1}{S(x)} \frac{\partial}{\partial x}\left[S(x) \frac{\partial p_{v, t}}{\partial x}\right]=\frac{1}{c^{2}} \frac{\partial^{2} p_{v, t}}{\partial t^{2}} \pm \frac{1 \cdot \rho}{S(x)} \frac{\partial v}{\partial t} \cdot b$.

Без другого члена справа це хвильове рівняння Вебстера.

Для конічного рупора:

$$
\frac{S(0)}{S(l)}=4
$$

$s(0) \cdot p(0)=S(x) \cdot p(x)$

$s(x)=\frac{1}{4} s(0)\left(\frac{2 l-x}{l}\right)^{2}$

3 (10) та (11) випливає, що:

$s(0) \cdot p(0)=\frac{1}{4} s(0)\left(\frac{2 l-x}{l}\right)^{2} \cdot p(x), \mathrm{i}$

$p_{v}(x, t)=4 p(0)\left(\frac{l}{2 l-x}\right)^{2} \cdot e^{j \omega\left(t-\frac{x}{c}\right)}$

$p_{t}(x, t)=4 p(0)\left(\frac{I}{2 I-x}\right)^{2} \cdot e^{j \omega\left(t-\frac{(2 I-x)}{c}\right)}$ 
Рівняння руху мембрани має вигляд:

$p_{v}(x, t)-p_{t}(x, t)=4 p(0)\left(\frac{1}{2 l-x}\right)^{2}\left[e^{j \omega\left(t-\frac{x}{c}\right)}-e^{j \omega\left[t-\frac{(2 l-x)}{c}\right]}\right]=$

$=4 p(0)\left(\frac{1}{2 l-x}\right)^{2} e^{j \omega\left(t-\frac{x}{c}\right)}\left[1-e^{j \omega 2\left(\frac{x-1}{c}\right)}\right]$,

де різниця тисків в каналах $\left(p_{v}-p_{t}\right)$ являє собою функцію збудження елемента мембрани.
Для частоти $f=1000$ Гц, $l=32 \mathrm{мм}, 0 \leq x \leq l$ :

$2 \omega\left(\frac{x-l}{c}\right) \ll<1,1-\cos 2 \omega\left(\frac{x-l}{c}\right) \approx 2\left(\omega \frac{x-l}{c}\right)^{2}, \mathrm{i}$ рівняння (12) приймає вигляд:

$p_{v, t}(x, t)=8 p(0)\left(\frac{1}{2 I-x}\right)^{2} \cdot\left(\cos \omega\left(t-\frac{x}{c}\right)\right) \cdot\left(\omega \frac{x-l}{c}\right)^{2}$

Результати розрахунків за формулою (13) при $t=0$ наведені у таблиці 1.

Таблиця 1. Залежність різниці тисків швидких хвиль стиснення в присінкових і барабанних сходах від координати

\begin{tabular}{|c|c|c|c|c|c|c|}
\hline$x / l$ & 0 & 0,2 & 0,4 & 0,6 & 0,8 & 1 \\
\hline$\frac{p_{v, t}(x)}{p(l)} \cdot 10^{2}$ & 3,6 & 2,86 & 2,00 & 1,45 & 0,35 & 0 \\
\hline
\end{tabular}

При $t \geq \frac{T}{4} \doteqdot \frac{1}{4 f} \square \frac{l}{c}$ :

$\frac{p_{v, t}(x, t)}{p(0)}=\frac{p_{v, t}(x, 0)}{p(0)} \cdot \cos \omega t$

Отже, можна зробити висновок, що наявність біжучої хвилі зміщення мембрани пов'язана з біжучою хвилею вимушеної сили, амплітуда якої задається коливанням стремінця. Біжуча хвиля в самій мембрані, у разі відсутності механічного зв'язку між елементами мембрани, взагалі не могла б розвиватися. Тому усі моделі окремої мембрани не мають фізичного сенсу, вірніше, відношення до завитки внутрішнього вуха.

Висновки. У роботі було проведено моделювання завитки внутрішнього вуха людини. Встановлено, що:

\section{Література}

1.Попов Ю. В. Гідромеханічне та електричне моделювання процесів передачі та перетворення АС в завитці органа слуху : автореф. дис. на здобуття наукового ступеня докт. біол. наук. спец: 03.00.02. / Ю. В. Попов Інститут отоларингології ім. проф. О.Коломійченка АМН України. - К., 2003. - 40 с. 2. Peterson L.C. A dynamical theory of the cohlea / L.C.Peterson, B.P.Bogert // JASA. -1950. - Vol.22.- p. 368-381.
1. Без врахування гнучкостей рейснерової і базилярної мембран різниця тиску на стінках завиткового ходу не перевищує 3,6 \% від тиску в ділянці овального вікна.

2. Розподіл різниці звукового тиску коливається в часі з частотою $w$.

3. Врахування гнучкості мембрани і залежності положення резонансів від $f$ визначаються неоднорідністю базилярної мембрани.

4. Біжуча хвиля різниці $p_{v t}(x, t)$ існує тільки поблизу резонансу на кожній частоті, де наростання амплітуди коливань до максимуму відбувається за багато періодів резонансної частоти.

5. Мале відносне значення амплітуди тиску біжучої хвилі могло стати причиною того, що робота Петерсона і Богерта не отримала подальшого розвитку.

3. Фланаган Дж. Л. Анализ, синтез и восприятие речи / Фланаган Дж. Л. : пер. с англ. / под ред. А. А. Пирогова. М. : Связь, 1968. - 394 с.

4. Вахитов Я. Ш. Теоретические основы электроакустики и электроакустическая аппаратура / Я. Ш. Вахитов - М. : 